\title{
Farmer nurseries as a catalyst for developing sustainable land use systems in southern Africa. Part A: Nursery productivity and organization
}

\author{
Andreas Böhringer ${ }^{\mathrm{a}, *}$, Elias T. Ayuk ${ }^{\mathrm{b}, 1}$, Roza Katanga ${ }^{\mathrm{c}}$, \\ Stephen Ruvuga ${ }^{\mathrm{d}}$ \\ anternational Centre for Research in Agroforestry-Southern Africa Program, PO Box 134, Zomba, Malawi \\ binternational Centre for Research in Agroforestry - Southern Africa Program, c/o DRSS, 5th Street \\ Extension, Harare, Zimbabwe \\ 'International Centre for Research in Agroforestry-Southern Africa Program, c/o Provincial Agricultural \\ Office, PO Box 510046, Chipata, Zambia \\ ${ }^{\mathrm{d} I n t e r n a t i o n a l ~ C e n t r e ~ f o r ~ R e s e a r c h ~ i n ~ A g r o f o r e s t r y-S o u t h e r n ~ A f r i c a ~ P r o g r a m, ~ c / o ~ H A S H I, ~ P O ~ B o x ~ 797, ~}$ \\ Shinyanga, Tanzania
}

Received 14 February 2002; received in revised form 9 October 2002; accepted 31 October 2002

\begin{abstract}
Trees play a critical role in the development of sustainable land use systems in the southern Africa region, but access to tree germplasm is limited. It was hypothesized that facilitating the establishment of farmer nurseries would promote decentralized tree seedling production in an efficient way, while at the same time provide opportunities for building natural, human and social capital. A study was conducted in Malawi, Zambia and Tanzania over 2 years to analyze the productivity of farmer nurseries and their functions in sustainable development. With limited outside support, farmers produced an estimated 6.2 million tree seedlings from 1901 nurseries across the three study areas over two years. Productivity of nurseries depended greatly on access to scarce water sources during the dry season. Farmers located the majority of nurseries therefore in ecologically sensitive dambo locations and along riverbanks, both posing possible land use conflicts in the future due to increasing human populations. Farmers organized two types of nurseries, with group nurseries producing significantly fewer tree seedlings compared to individual nurseries. This was attributed to larger transaction costs associated with organization and capacity building of group nurseries. On the other hand, the success of individual nurseries appeared to depend on human and social "start-up" capital

* Corresponding author. Tel.: + 265-535393; fax: + 265-534283

E-mail addresses: aboehringer@malawi.net (A. Böhringer), eayuk@idrc.org.sn (E.T. Ayuk), rkatanga@zamnet.zm (R. Katanga), sruvuga@africaonline.co.tz (S. Ruvuga).

${ }^{1}$ Present address: IDRC/SISERA, PO Box 11007, CD Annex, Dakar, Sénégal.
\end{abstract}


being provided by group nurseries through previous training. In the absence of rigorous valuation of the longer-term effects of both types of nurseries in building natural, human and social capital, it appears that both have a role to play in meeting local demand for tree seedlings. Results generally suggest that smallholder farmers can play a pivotal role in providing tree germplasm for the development of sustainable land use systems.

(C) 2003 Elsevier Science Ltd. All rights reserved.

Keywords: Natural capital; Nursery productivity; Human capital; Social capital; Sustainable development; Tree germplasm

\section{Introduction}

Sustainable development should focus in general on creating more opportunities for future generations to achieve growth in natural, human and social capital (Serageldin and Grootaert, 2000). The importance of natural capital has been gaining wider recognition recently. This has led to a paradigm for natural resource management being proposed linking concepts of ecology and economics to guide agricultural research towards increased development impact (Izac and Sanchez, 2001). It is increasingly being argued that wider impact on poverty and environmental degradation can only be achieved, if building of human and social capital receives simultaneous and equal attention as having been the case with natural capital (Serageldin and Grootaert, 2000; Woodhill and Röling, 1998).

The southern Africa region faces tremendous development challenges. Increasing levels of poverty, food insecurity and degradation of the natural resource base are key problems that need to be addressed very urgently. Agroforestry, which involves the integration of trees into agricultural landscapes, has the potential to contribute to food security, generate income and arrest the degradation of the environment (Sanchez and Leakey, 1997). Feasible and profitable agroforestry options are now emerging in the region that already provide significant benefits to large numbers of smallholder farming households, such as allowing farmers to increase soil fertility without relying on expensive inputs. The challenge is now to scale up this potential with many more households in order to yield meaningful impact at the regional level (Böhringer et al., 1999; Böhringer, 2001).

There is little empirical evidence from the southern African region about the significance of trees in sustainable land use at the community and watershed levels. However, there is a wealth of information on farmers' use and their valuation of trees on farms, indicating overall that trees do play an important role in enhancing farm productivity, diversification, food security, household incomes and ecosystem services (Dewees, 1995b; Place and Dewees, 1999; Place and Otsuka, 2001). Farmers have not only been protecting useful natural trees on their farms for ages, but also have been actively planting trees either by transplanting naturally occurring volunteer seedlings or by obtaining seedlings from whatever source they could access (Aalbaek, 2001; Dewees, 1995a,b; Guggenberger et al., 1989).

One of the major constraints farmers face in intensifying and diversifying land use with trees is lack of access to adequate germplasm, i.e. tree seed and seedlings 
(Aalbaek, 2001; Böhringer et al., 1999; Francis, 1995; Place and Dewees, 1999; Guggenberger et al., 1989). In the past, government subsidized central nurseries represented the main source of tree seedlings in rural areas, but this supply was not based on farmers' demand but rather on ill-perceived national or institutional policies, which failed to address the complex sustainability needs of household in terms of food security and farm diversification (Dewees, 1995a,b; Guggenberger et al., 1989). In addition, due to the on-going economic restructuring and market liberalization in the region, most of the few surviving central nurseries today have low seedling output and are unable to meet demand (Forestry Research Institute of Malawi, personal communication; Chendauka Bwalya, undated and unpublished review of nurseries in Zambia).

It is hypothesized that building farmers' own capacity in producing tree seedlings represents an efficient way in meeting rural demand for tree planting. In the wider context of sustainable development, it is further hypothesized that facilitating the establishment of such farmer nurseries acts as a catalyst in building natural, human and social capital at the grass root level. Looking at farmer nurseries from the perspective of an investment into sustainable development, this paper makes a case for adding human and social capital dimensions (Fig. 1) to the natural resource one proposed by Izac and Sanchez (2001). Here natural capital relates specifically to the establishment, productivity and tree planting impact of farmer nurseries. Human capital refers to capacities built in operating tree nurseries, while social capital relates to the organizational aspects of these nurseries and how they relate to wider community development (Fig. 1).

The overall objective of this paper is to assess the role and functions of farmer nurseries in building capital for the development of sustainable land use systems. The specific objectives of this first part of the paper are to assess the productivity of farmer nurseries and to examine how their organization affects nursery output. A second part will focus on the role of support systems in facilitating farmer nurseries, assess the early impact of tree planting and discuss policy issues related to the use of trees in developing sustainable land use systems in southern Africa.

\section{Materials and methods}

\subsection{Study sites}

The study focused on three regions/provinces: Shinyanga Region of Tanzania, Eastern Province of Zambia and Southern Region of Malawi (for ease, subsequently referred to by country names). These sites were chosen because they are three of ICRAF's pilot areas for agroforestry research and development in the region (Böhringer, 2001). The three areas receive similar average annual rainfall ranging between 600 and $800 \mathrm{~mm}$ in Tanzania, and $800-1000 \mathrm{~mm}$ in Zambia and Malawi. One important landscape feature common to all countries are seasonally waterlogged, low lying areas, locally called dambo, which due to their higher ground water table often provide the only opportunity for off-season cropping to smallholder 
farmers. Key land use indicators for the three study areas are given in Table 1. They show marked differences in average population density and hence cropping area available to households. Malawi has one of the highest population densities on record in similar environments in Africa, with land becoming the major farming system constraint next to labor, while in Tanzania and Zambia available labor primarily limits productivity (Böhringer, 2001). Accordingly, pressure on trees in remaining natural forests and woodlands is approximately 10 times higher in Malawi than in Zambia (Table 1).

\begin{tabular}{|c|c|c|}
\hline & The development process & \\
\hline \multirow[t]{2}{*}{$\begin{array}{l}\text { Reversing depletion of } \\
\text { capital stocks }\end{array}$} & $\longrightarrow$ Catalyst__ & Sustainable capital growth \\
\hline & $\begin{array}{c}\text { Farmer nurseries in } \\
\text { sustainable development }\end{array}$ & \\
\hline Development function & Objectives & Outcomes ${ }^{*}$ \\
\hline Growth in natural capital & $\begin{array}{l}\text { To increase the supply and } \\
\text { diversity of germplasm in } \\
\text { order to meet demand for } \\
\text { tree planting on farms }\end{array}$ & $\begin{array}{l}\text { - } \\
\text { - } \text { Foil fertility replenished } \\
\text { increased } \\
\text { - } \quad \text { Tree stocks increased } \\
\text { - } \text { Bio-diversity and eco- } \\
\text { system resilience } \\
\text { enhanced }\end{array}$ \\
\hline Growth in human capital & $\begin{array}{l}\text { To enhance farmers' } \\
\text { knowledge and skills in } \\
\text { germplasm production and } \\
\text { tree management }\end{array}$ & $\begin{array}{l}\text { - Science applied and } \\
\text { integrated with } \\
\text { indigenous knowledge } \\
\text { - Innovation enhanced } \\
\text { - Self-esteem, articulation } \\
\text { and entrepreneurial spirit } \\
\text { restored }\end{array}$ \\
\hline \multirow[t]{2}{*}{ Growth in social capital } & $\begin{array}{l}\text { To promote farmer } \\
\text { organization, community } \\
\text { trust and leadership }\end{array}$ & $\begin{array}{l}\text { Solidarity increased and } \\
\text { social conflicts reduced } \\
\text { - Well-coordinated and } \\
\text { self-reliant social action } \\
\text { functional, showing } \\
\text { impact on development } \\
\text { and policy change }\end{array}$ \\
\hline & $\begin{array}{c}\text { The evolution of farmer } \\
\text { nurseries }\end{array}$ & \\
\hline $\begin{array}{l}\text { Low-cost trees for basic } \\
\text { food security and } \\
\text { ecosystem rehabilitation }\end{array}$ & & $\begin{array}{l}\text { High-value trees for increasing } \\
\text { incomes }\end{array}$ \\
\hline
\end{tabular}

* at the household and community level

Fig. 1. A conceptual framework of farmer nurseries acting as a catalyst in building natural, human and social capital for sustainable rural development. 
Table 1

Selected land use indicators at three study areas in southern Africa, Shinyanga Region of Tanzania, Eastern Province of Zambia and Southern Region of Malawi

\begin{tabular}{|c|c|c|c|}
\hline Study area/indicator & 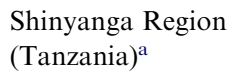 & $\begin{array}{l}\text { Eastern Province } \\
\text { (Zambia) }^{\mathrm{b}}\end{array}$ & $\begin{array}{l}\text { Southern Region } \\
\text { (Malawi) }^{\mathrm{c}}\end{array}$ \\
\hline Total land area $\left(\mathrm{km}^{2}\right)$ & 50,781 & 69,000 & 31,753 \\
\hline Total Population (Million) & 2.61 & 1.23 & 4.63 \\
\hline Rural population ( $\%$ of total) & 93.4 & 89.2 & 84.7 \\
\hline Average population density (people $\mathrm{km}^{-2}$ ) & 51 & 18 & 146 \\
\hline Land area under forests/woodland (\%) & 14.0 & 8.0 & 7.1 \\
\hline $\begin{array}{l}\text { Population pressure on forests/woodland } \\
\text { [people } \mathrm{km}^{-2} \text { forests/woodland) }\end{array}$ & 367 & 223 & 2054 \\
\hline Average cropping area per household (ha) & 3.20 & 1.58 & 0.76 \\
\hline
\end{tabular}

a Data extracted from: Jamhuri ya Muungano wa Tanzania, 1999. Hali ya Uchumi na Maendeleo ya Jamii Mkoa wa Shinyanga (Tume ya Mipango), Dar es Salaam na Ofisi ya Mkuu wa Mkoa, Shinyanga, Dar es Salaam, National Printers.

b Data extracted from three sources: (1) Central Statistical Office, 1996, The evolution of poverty in Zambia (1991-1996), Lusaka, Zambia. (2) Farming System Research Team Eastern Province, 1999, 1998/ 1999 Annual Report, Department of Research and Specialist Services, Ministry of Agriculture, Food and Fisheries, Chipata, Zambia. (3) Central Statistical Office, 1997, 1996/1997 Post-Harvest Survey, Lusaka, Zambia.

c Data extracted from three sources: (1) National Statistical Office, 2000, 1998 Malawi population and housing census - report of final census results, Zomba, Malawi: National Statistical Office. (2) National Economic Council-Poverty Monitoring System, 2000, Detailed tables for a poverty profile of Malawi, 1998, Lilongwe, Malawi: Government of Malawi (Poverty Monitoring System). (3) Malawi GovernmentEnvironmental Affairs Department, 2000, Lake Chilwa Wetland State of the Environment, Lilongwe, Malawi.

\subsection{The process of scaling-up farmer nurseries}

Research and development activities in the region aim at accelerating impact by studying how the use of agroforestry can be scaled up. The most important constraints to wider adoption of technologies are limited awareness of agroforestry options, inadequate capacities of partners and farmers and lack of access to adequate germplasm. All three have been identified during stakeholder planning workshops conducted in Malawi, Tanzania, Zambia and Zimbabwe (Böhringer et al., 1999).

Awareness is created through disseminating various information materials and by scaling-out agroforestry information and germplasm through networking with a wide range of partners coming from the government, non-government and private sectors (Böhringer, 2001). Facilitating field demonstrations, training and exchange programs are building agroforestry capacities of partners and farmers. To overcome the constraint on limited available tree germplasm, the main thrust promotes decentralized, grass root level production and distribution systems, where facilitating the establishment of farmer nurseries is emerging as one of the main pathways (Böhringer, 2001). 
The process of scaling-up farmer nurseries followed a similar pathway in all the three study areas. Field days were organized at research sites and/or farmers' fields and these created the initial demand for nurseries at the local level. Partners identified clusters of 20-30 interested farmers, at least half of them being women. A date for field training was arranged, ideally at least 2 months before the expected onset of rains (August-November). The training was practical and skill oriented, with one physical outcome being that trainees established a model nursery and sowed tree seed in beds. In Zambia and Malawi, nursery production focused on low-cost, barerooted seedlings produced for use in soil fertility replenishment (Kwesiga and Beniest, 1998). In Tanzania, seedlings were raised in polyethylene bags, which were provided free of charge to farmers by a government re-forestation project. At the end of every training event, each participating farmer received a small quantity of tree seed to cater for first season plantings. In case of soil fertility replenishment technologies, quantities given were enough to plant a 0.25 ha large agroforestry plot. Species distributed depended on requests made earlier and on availability of germplasm. In Zambia and Malawi, two species were largely made available (Sesbania sesban and Gliricidia sepium). In Tanzania, a number of other fruit, fodder and forestry species were also made available by a government re-forestation project. Leaflets, which described the whole nursery process in local language, accompanied the distribution of tree seed. Farmers then decided on their own, whether they wanted to form groups and pool tree seed received or whether they wanted to go on their own and establish individual nurseries. ICRAF staff and partners visited nurseries at least once during seedling establishment. At the time of transplanting, between November and January, project staff facilitated field demonstrations, which brought clusters of nursery farmers together, in a selected farmer field. Knowledgeable and skillful farmers were used as trainers and in carrying out these demonstrations. Finally, farmers organized the distribution of seedlings from nurseries according to their own preferences. This meant that not everyone receiving tree seedlings might have attended previous training or field demonstrations.

\subsection{Survey methods and data analysis}

A total of 426 nurseries were randomly sampled in the three locations over two seasons. In Malawi, the sample size was 163 and 88 nurseries and in Zambia 40 and 62 nurseries in 1998/1999 and 1999/2000 seasons, respectively. In Tanzania, 73 nurseries were surveyed in the 1998/1999 growing season only. The total number of nurseries recorded by ICRAF and partners, representing the sampling population for this study, are summarized by country and year in Table 2. The majority of survey forms were filled directly by ICRAF staff between the months of December and February each year, but some were also completed together with partner staff. A team of ICRAF field assistants in each country was trained in carrying out the survey. Country survey teams were consistent across years. In case of partner staff assisting in the survey, at least one ICRAF field assistant was present to ensure that the survey protocol was uniformly implemented. During visits to nurseries, interviews with participating farmers were conducted to characterize sites and to discuss 
Table 2

Total number of farmer nurseries recorded by ICRAF and partners and total nursery output in three study areas of southern Africa over two growing seasons (1998-2000)

\begin{tabular}{|c|c|c|c|c|c|c|}
\hline \multirow{2}{*}{$\begin{array}{l}\text { Growing season } \\
\text { Study area }\end{array}$} & \multicolumn{3}{|l|}{$1998 / 1999$} & \multicolumn{3}{|l|}{$1999 / 2000$} \\
\hline & $\begin{array}{l}\text { Number } \\
\text { of } \\
\text { nurseries } \\
\text { recorded }^{\text {a }}\end{array}$ & $\begin{array}{l}\text { Number } \\
\text { of } \\
\text { nurseries } \\
\text { sampled }\end{array}$ & $\begin{array}{l}\text { Total } \\
\text { number of } \\
\text { tree seedlings } \\
\text { produced }^{\mathrm{b}}\end{array}$ & $\begin{array}{l}\text { Number } \\
\text { of } \\
\text { nurseries } \\
\text { recorded }\end{array}$ & $\begin{array}{l}\text { Number } \\
\text { of } \\
\text { nurseries } \\
\text { sampled }\end{array}$ & $\begin{array}{l}\text { Total } \\
\text { number of } \\
\text { tree seedlings } \\
\text { produced }^{\mathrm{b}}\end{array}$ \\
\hline Shinyanga, Tanzania & 150 & 73 & 234,379 & 288 & $\mathrm{~N} / \mathrm{A}$ & $\mathrm{N} / \mathrm{A}$ \\
\hline Eastern Province, Zambia & 204 & 40 & 121,244 & 339 & 62 & 167,498 \\
\hline Southern Region, Malawi & 303 & 163 & 579,159 & 617 & 88 & $1,600,104$ \\
\hline Total & 657 & 276 & 934,782 & 1244 & 150 & $1,767,602$ \\
\hline
\end{tabular}

a Note that numbers indicated are the ones ICRAF and partners were able to record; total actual numbers of nurseries established by farmers in each location are expected to be higher.

b Refers to actual number of tree seedlings produced in nurseries sampled (previous column); 1999/ 2000 survey only covered Zambia and Malawi.

nursery establishment and management. Number of seedlings produced was calculated by counting actual seedlings in nursery beds at time of distribution.

Data were analyzed in two sets, namely the three countries pooled for the 1998/ 1999 growing season and Malawi and Zambia data combined over two growing seasons. Regression analysis and independent sample tests (two-tailed $t$-tests assuming unequal variances) were carried out to determine the statistical importance of the effects of country, nursery location and organization on a number of nursery productivity indicators.

\section{Results and discussion}

\subsection{Nursery establishment}

\subsubsection{Location}

Ease of access to water was a key determinant for the location of nurseries across the three study areas in 1998/1999. The total number of nurseries located in dambo sites was $50.5 \%, 35.6 \%$ along riverbanks and $11.6 \%$ within home yards. Only $1.8 \%$ of all nurseries were placed in fields and $0.4 \%$ close to boreholes. A similar distribution was observed in Zambia and Malawi across the 2 years. Accordingly, $47.6 \%$ of all nurseries were watered from self-dug waterholes and $47.3 \%$ from rivers, the latter particularly important in Malawi (60.1\% of country total). The high proportion of nurseries situated next to rivers in Malawi $(52.4 \%)$ also reflected the land scarcity situation observed there, where prime agricultural land in dambo locations has now come under severe pressure, in particular from vegetable and tobacco growers (Place and Dewees, 1999). This has important implications for the sustainability of farmer tree nurseries in dambo locations in respect to different land use 
objectives. Our own observations suggest furthermore that flat land along the often steep river banks in the Shire highlands of Malawi is generally restricted, meaning that the opportunity costs for establishing and watering nurseries were usually higher there than in dambo locations. Intensive cultivation along such riverbanks today, is showing negative impacts on riparian vegetation leading to considerable levels of stream bank erosion. The sustainable use of land in such ecologically sensitive locations needs to be taken into consideration when promoting farmer nurseries.

Nursery establishment at both locations still remains a risky venture, as water supply often ceases during the long dry season. The results on sources of water for nursery establishment also underline the crisis in rural water supply in the region, where self-dug water holes and rivers still provide the main source for domestic water use for the large majority of households. In the Southern Region of Malawi for instance, only $4.9 \%$ of rural households are reported to have access to piped water (Malawi National Statistical Office, personal communication). Against this background, expanding nurseries might lead to an increase in conflicts over this already scarce resource, especially during the dry season.

\subsubsection{Organization}

About $59.3 \%$ of all nurseries were operated as group and $40.7 \%$ as individual nurseries. One individual farmer or household operated individual nurseries, whereas group nurseries were those being operated by more than one farmer coming from different households. Both types of nurseries are generally operated for several seasons with the main objective being to cater for own seedling demand. However, differences in length of operation and changes in nursery objectives were not explicitly assessed in this study, but this warrants further investigation in the future in order to allow a better understanding on differences in organizational dynamics between individual and group nurseries and how they affect nursery productivity. Membership of group nurseries varied between countries having on average 5.5 members in Zambia, 13.6 in Malawi and 10.7 in Tanzania (standard deviation was 4.7, 8.8 and 8.6, respectively). There was a distinct difference in proportions of individual and group nurseries between Zambia and Tanzania on the one hand and Malawi on the other. The former two countries had 4.6 and 3.6 times more individual than group nurseries, respectively. In Malawi the number of group nurseries was 6.1 times the number of individual ones. These differences in organization cannot be explained by different nursery objectives, since in all three countries tree seedlings were produced primarily for own use and not for sale. Group nurseries in Malawi were of great importance because of much higher population densities resulting in restricted access to land and reliable water sources during the dry season. This has made the organized sharing of these scarce resources a necessity. Furthermore, lower population density and more scattered settlements in Tanzania and Zambia probably meant higher transaction costs for organizing groups and transport logistics, explaining why individual nurseries were the preferred type.

Only $9.5 \%$ of all nurseries sampled in 1998/1999 were operated for the first time while the remaining majority had at least one member who had previous experience 
in operating similar agroforestry nurseries. In the following season, this pattern remained the same in Malawi, while in Zambia it was different with $87 \%$ of the total number reporting to be first time nurseries. This difference between survey years occurred because the sites for the latter year were in new areas that have been targeted by an international non-government organization.

\subsection{The productivity of farmer nurseries}

The productivity of farmer nurseries is examined within the context of their functions in building natural, human and social capital. Selected key parameters are examined for each.

\subsubsection{Natural capital}

The main parameters of interest are total productivity, establishment (see Section 3.1), species diversity, and tree planting impact. Tree planting impact is assessed in the second part of this paper and is not discussed here. In 1998/1999, the 276 farmer nurseries surveyed (Table 2) produced an overall total of 934,782 tree seedlings in the three countries. In the following season $(1999 / 2000)$ the 150 nurseries sampled in Zambia and Malawi produced about 1,767,602 tree seedlings (Table 2). It can be estimated that the total output from all recorded nurseries in the three countries (Table 2) was approximately 4.03 million seedlings. Malawi accounted for over half of this production or 2.19 million seedlings alone. Combining both years, the overall production in 1901 farmer nurseries (Table 2) is estimated at 6.2 million tree seedlings across the three locations. These figures are many-fold higher than those reported for government subsidized nurseries in Zambia and Malawi (Chendauka Bwalya, undated and unpublished review of nurseries in Zambia; Forestry Research Institute of Malawi, personal communication).

Productivity of farmer nurseries in the three study areas during the 1998/1999 season is summarized in Table 3. Using average number of tree seedlings produced per nursery (Table 3), over 2.17 million seedlings were raised in all farmer nurseries across the three sites in 1998/1999. The average production figures in Tanzania are within the range reported by Aalbaek (2001) in his national survey. The tree

Table 3

Average productivity of farmer nurseries in three study areas in southern Africa during the 1998/1999 growing season

\begin{tabular}{|c|c|c|c|}
\hline Study area/productivity indicator & $\begin{array}{l}\text { Shinyanga Region, } \\
\text { Tanzania }\end{array}$ & $\begin{array}{l}\text { Eastern Province, } \\
\text { Zambia }\end{array}$ & $\begin{array}{l}\text { Southern Region, } \\
\text { Malawi }\end{array}$ \\
\hline Average number of species raised & $4.62(0.89)^{\mathrm{a}}$ & $1.38(0.14)$ & $1.99(0.10)$ \\
\hline $\begin{array}{l}\text { Average total number of seedlings } \\
\text { raised per nursery }\end{array}$ & $3210.7(1293.3)$ & $3031.1(634.5)$ & $3553.1(348.0)$ \\
\hline $\begin{array}{l}\text { Average total number of seedlings } \\
\text { raised per individual farmer }\end{array}$ & $547.2(199.9)$ & $2112.9(396.1)$ & $530.1(70.0)$ \\
\hline
\end{tabular}

a Numbers in parentheses are standard errors of means. 
seedlings being produced have a huge potential of playing a major part in building the natural resource base especially for those species that are used for replenishing soil fertility. The number of seedlings produced per individual is used as an indicator for comparing productivity across nursery types (i.e. individual versus group) and sites. A linear regression analysis using nursery output per individual as a dependent variable and study area, nursery location, nursery type, nursery method and number of species raised as explanatory variables was highly significant with an adjusted $R^{2}$ of 0.279 - a value that is reasonable for such cross sectional data.

Independent sample tests between study areas in 1998/1999 showed significantly higher numbers of seedlings produced per individual in Zambia than in the other two sites (Table 3). Differences in number of seedlings produced in Zambia compared to Malawi and Tanzania were highly significant ( $t$-values: 0.000 and 0.001 , respectively), while seedling productivity between Malawi and Tanzania was not statistically different (Table 3). Similarly, productivity in Zambian nurseries was much higher over the two years in comparison to those recorded in Malawi, with means of 2173 and 938 seedlings, respectively. Higher nursery productivity in Zambia was due to larger land-holdings and fallowing still being widely practiced (Table 1). The need to plant larger areas with improved fallows, a soil fertility technology that is based on transplanting large numbers of bare-rooted seedlings (Kwesiga and Beniest, 1998), is probably the reason explaining the significantly higher number of tree seedlings raised per individual in Zambia. Since land availability is similar in Tanzania (Table 1), the lower production of seedlings per individual there can be explained by differences in species raised and nursery methods used. Trees of higher value such as fruit tree seedlings were exclusively raised in polythene bags allowing Tanzanian farmers to utilize the larger diversity of germplasm that was made available through the government reforestation project. This result also indicates that there could be a trade-off between quantity and quality of seedlings produced, but this needs to be verified in the future by paying more attention to measuring seedling quality. Lower nursery productivity in Malawi can firstly be explained by the fact that farmers own much less land for cropping (Table 1) restricting space for planting of trees. Secondly, it is probably due to the fact that the majority of nurseries were of the group-type (85.9\%). These have been shown to produce consistently less seedlings per individual.

Caution needs to be exercised in interpreting these results. It does not necessarily follow that high seedling output is always the desired objective of farmers' nurseries. Most often the level of productivity will depend on a variety of factors including the intended use of the seedlings and availability of land and labor. In the case of fruit trees, for instance, farmers will produce only the quantity that would meet their own needs, with excess only being produced, if there are markets for sale of seedlings. Furthermore, it follows that higher nursery productivity does not necessarily mean more sustainable land use, since the latter depends on actual number of trees being transplanted into the landscape and their rate of survival.

Table 3 shows that there was higher species diversity in Tanzania (4.62) compared to Zambia (1.38) and Malawi (1.99). The maximum number of species raised were five in Zambia, eight in Malawi and 65 in Tanzania, showing that farmers' access to 
diverse germplasm remained limited in the first two countries. However, analysis showed that number of species raised was not significant in explaining the variation in nursery productivity. Species diversity should be seen as another important criterion in assessing the role of nurseries in developing sustainable land-use systems. It was noted that diversity was significantly higher in Tanzania ( $t$-value: 0.029$) \mathrm{com}$ pared to the other two sites (Table 3). The free distribution of polythene bags must have also contributed to this higher diversity, as this method is considered more cost-efficient and appropriate in raising smaller numbers of higher value trees compared to raised beds, the latter being more efficient for mass production of fewer species (Kwesiga and Beniest, 1998). It is interesting to note here that nursery type had no effect on species diversity, and this was true for analyses across countries as well as within Tanzania with group and individual nurseries producing similar number of species.

Species diversity was the only indicator assessed in this study that could be considered as qualitative. As farmer nurseries evolve and move from production of lowcost tree seedlings for basic food security and ecosystem system services to highervalue ones for incomes (Fig. 1, bottom), it can be expected that the quality of individual tree seedlings produced will increase in importance. Previous research has also pointed out that decentralized tree germplasm systems may perform well in terms of meeting required quantities, but could fall short on quality and diversity goals of society (Place and Dewees, 1999). In general, our results indicate that productivity of farmer nurseries in quantitative terms was governed by nursery type. While in qualitative terms, as measured in species diversity, more technical aspects such as nursery method appeared to be of greater importance. For species diversity, it has to be kept in mind that availability of different species to farmers is naturally of overriding importance. The aspect of tree seedling quality needs to be given more attention in future assessments, to keep pace with the anticipated evolution of farmer nurseries where diversity and high-value tree seedling production are expected to become more important over time (Fig. 1). As increased species diversity is closely related to increasing biodiversity, it is an important element of building natural capital.

\subsection{Human capital}

Results from this study suggest that, as skills are acquired the productivity of farmer nurseries increased. When comparing seedling productivity within Zambia across years, a significant difference ( $t$-value: 0.013 ) was observed, with 2100 seedlings produced in the 1998/1999 season compared to 926 seedlings in the following 1999/2000 season. Differences in seasonal conditions cannot explain this much lower productivity in Zambia during the second year alone, since locations in Malawi and Zambia shared similar environments. Analysis within Zambia showed that first time nursery operators produced significantly less seedlings $(P=0.043), 961$ on average compared to more experienced ones producing on average 2268 seedlings. Assuming that demand for seedlings was also similar in both seasons, this difference then points to the importance of skills and experience in nursery productivity, attributes 
associated with human capital (Fig. 1). The consistent average production in Malawi across both years of 588 seedlings also supports this explanation, with almost all nurseries reporting to have had some previous experience in nursery establishment. A $50 \%$ decrease in nursery output should therefore be anticipated with first time nurseries compared to ones operated by farmers having acquired skills and experience previously.

\subsection{Social capital}

The catalytic dimensions of farmer nurseries are exemplified by nursery type and inter-group dynamics. Running a model based on nursery type as the only prediction variable resulted in a significant regression $(P<0.0005)$ with an adjusted $R^{2}$ of 0.204 . This means that nursery type, a variable that is related to social capital (Fig. 1), was significant in explaining seedling production in farmer nurseries. This was also confirmed in the analysis considering nursery productivity in Zambia and Malawi over 2 years. Here, nursery type (Beta coefficient: -0.402 ) was in fact the only significant predictor in the model ( $t$-value: 0.000 and $\left.R^{2}=0.179\right)$, with year, country, and nursery location as well as nursery method making no meaningful contribution at all in explaining variation.

As mentioned above, type of nursery had a significant effect on number of seedlings produced ( $t$-value: 0.000 ), with individual and group nurseries producing on average 1834 and 393 seedlings, respectively, across study sites in 1998/1999. Similarly, when comparing nursery types in Zambia and Malawi over two years, individual nurseries produced on average 1500 seedlings more than groups ( $t$-value: 0.000 ). Individual nurseries in Zambia and Malawi produced on average 1855 and 872 seedlings more, respectively. This difference in productivity between individual and group nurseries can be interpreted as a kind of trade-off between the two broader nursery objectives aiming at building natural and social capital (Fig. 1).

The importance of inter-group dynamics is evident in the productivity levels of the different types of nurseries. The highest productivity was achieved in individual nurseries where little social transaction costs are incurred and individual effort counted most. On the other hand, group nurseries had to bear additional transaction costs on organization at the expense of productivity, while offering group members in return the benefit of spreading overall production risks. In support of this explanation, members of group nurseries frequently cited quarrels over sharing of nursery labor and seedlings produced. We found during nursery visits that this often resulted directly into sub-optimal care of seedlings explaining hence lower nursery output per individual group member. Others have also suggested that complex incentive structures are needed when forming community tree nurseries (Place $\&$ Dewees, 1999). This suggests that more research would be required in defining longer-term trade-offs between support to individual and group nurseries. It is also important to determine the different kind of incentives they would need in order that they can contribute in a balanced way to the building of different kinds of capital (Fig. 1). Without such valuation of the longer-term effects of both types of nurseries 
in building different kind of capital (Fig. 1), our results suggest that a decision to favor one over the other in sustainable development appears to be unjustified. This has to be seen against the fact that most projects in the region advocate group approaches in smallholder farmer extension, because they supposedly allow larger numbers of farmers to be reached in much shorter time and at lower costs.

\section{Conclusions}

Establishing nurseries and producing tree seedlings are feasible options for smallholder farming households in the region. With outside support being largely limited to provision of germplasm and capacity building, farmers produced an estimated 6.2 million tree seedlings from 1901 nurseries across the three study areas over 2 yearsan output that is much higher than the ones achieved in subsidized central nurseries operated by the government sector. However, with further scaling-up of farmer nurseries, it has to be anticipated that labor and water will become more binding constraints in achieving similar nursery outputs. Nurseries depended first of all on scarce water sources during the dry season, the majority being located in ecologically sensitive dambo locations and along riverbanks. Both locations are coming under increasing pressure from different land-user groups, with supply of water for domestic use remaining the prime concern to the majority of households. Conflicts over dry season water sources are therefore likely to become focal issues in negotiating ecologically compatible and socially acceptable land use systems in the region. Future support and scaling-up of farmer nurseries have to take this into consideration. Productivity of farmer nurseries appeared to be intrinsically linked to three wider development objectives of building natural, human and social capital. A number of trade-offs between building different kinds of capital were indicated, such as by differences observed in productivity between the two types of farmer nurseries. Group nurseries produced significantly fewer tree seedlings, probably due to larger transaction costs for organization and capacity building than those incurred by individual nurseries. The success of individual nurseries appears attributable to human and social "start-up" capital that is generated by group nurseries at earlier stages. However, the effects of building of human capital on social organization of nurseries and its dynamics over time need closer investigation in the future, to allow a better assessment of the different kinds of capital that are being built.

In the absence of better valuation of the longer-term effects of both types of nurseries in building diffent kinds of capital, it appears that both have an important role to play in meeting demand for tree seedlings in a decentralized way. Further differentiation of nursery types is warranted in the future to allow better targeting of incentives and support systems. Such support should focus on building farmers capacities so as to enable them to respond effectively to changes in demand for trees and diversify seedling production. It appears that smallholder farmers can play a pivotal role in providing tree germplasm for the development of sustainable land use systems, provided that their particular resource limitations and livelihood strategies are carefully taken into consideration. 


\section{Acknowledgements}

We are grateful to the Canadian International Development Agency (CIDA) for the financial support given to ICRAF to carry out the research reported in this paper through funding of the project "Agroforestry for Sustainable Rural Development in the Zambezi River Basin, Southern Africa Region" (R/C Project 050/ 19425, Agreement 23591). We thank the ICRAF-SA team for support in the implementation of this study in particular the Country Leaders, Paramu Mafongoya (Zambia), Jumanne Maghembe (Malawi) and Robert Otsyina (Tanzania), as well as the Regional Coordinator, Freddie Kwesiga. The authors have benefited from comments on an earlier version of this paper by Diane Russell and Steve Franzel (ICRAF) and two anonymous reviewers of the journal. The inputs from Frank Place in reviewing the final version of this paper were highly valued. Lastly, we would like to thank our partners and farmers who have been participating in farmer nurseries since the 1997/1998 growing season. All errors and omissions are the responsibilities of the authors.

\section{References}

Aalbaek, A., 2001. Access to Planting Material as a Major Constraint to Farmer Tree Planting: A National Investigation of Farmer Tree Planting and Nursery Production in Tanzania. PhD Dissertation, Department of Economics and Natural Resources, Royal Veterinary and Agricultural University, Denmark.

Böhringer, A., 2001. Facilitating the wider use of agroforestry for development in southern Africa. Development in Practice 11 (4), 434-448.

Böhringer, A., Katanga, R., Makaya, P.R., Moyo, N., Ruvuga, S., 1999. Planning for collaboration in agroforestry dissemination in southern Africa. Southern Africa Agroforestry Development Series No. 1. International Centre for Research in Agroforestry, Makoka, Malawi.

Dewees, P.A., 1995a. Forestry policy and woodfuel markets in Malawi. Natural Resources Forum 19 (2), $143-152$.

Dewees, P.A., 1995b. Trees on farms in Malawi: private investment, public policy, and farmer choice. World Development 23 (7), 1085-1102.

Francis, K.J., 1995. The use of PRA in monitoring forestry projects: experiences from Tanzania. Ann. For. 3 (2), 105-114.

Guggenberger, C., Ndulu, P., Shepherd, G. 1989. After Ujama: farmer needs, nurseries and project sustainability in Mwanza, Tanzania. The Overseas Development Institute (Agricultural Administration Unit), London.

Izac, A.-M.N., Sanchez, P.A., 2001. Towards a natural resource management paradigm for international agriculture: the example of agroforestry research. Agricultural Systems 69, 5-25.

Kwesiga, F., Beniest, J., 1998. Sesbania Improved Fallows for Eastern Zambia: An Extension Guideline. International Centre for Research in Agroforestry, Nairobi, Kenya.

Place, F., Dewees, P., 1999. Policies and incentives for the adoption of improved fallows. Agroforestry Systems 47 (1-3), 323-434.

Place, F., Otsuka, K., 2001. Tenure, agricultural investment and productivity in the customary tenure sector of Malawi. Economic Development and Cultural Change 50 (1), 77-99.

Sanchez, P.A., Leakey, R.R.B., 1997. Land use transformation in Africa: three determinants for balancing food security with natural resource utilization. European Journal of Agronomy 7, 15-23. 
Serageldin, I., Grootaert, C., 2000. Defining social capital: an integrating view. In: Dasgupta, P., Serageldin, I. (Eds.), Social Capital-A Multifaceted Perspective. The International Bank for Reconstruction and Development, Washington, DC, USA, pp. 40-58.

Woodhill, J., Röling, N.G., 1998. The second wing of the eagle: the human dimension in learning our way to more sustainable futures. In: Röling, N.G., Wagemakers, M.A.E. (Eds.), Facilitating Sustainable Agriculture. Cambridge University Press, Cambridge, UK, pp. 46-71. 